\title{
Rejestry nieruchomości w dawnej Polsce
}

\section{Pierwsze próby rejestrowania umów przeniesienia własności i za-} kładania ksiąg gruntowych. W średniowiecznej Polsce skuteczne nabycie praw do posiadania nieruchomości wymagało odrębnego aktu (wwiązania), stanowiącego dowód wejścia nabywcy $w$ ich władanie ${ }^{1}$. $Z$ tego też powodu wydanie nabywcy gruntów łączyło się z koniecznością wytyczenia ich granic poprzez obejście lub objazd konny, jak i z obowiązkiem sporządzenia szczegółowego pisemnego ich opisu, „który w razie potrzeby mógł służyć za dowód w sporze"2. W przypadku posiadłości o mniejszej wartości akt ten ograniczał się czasem do publicznego (w obecności świadków) złożenia pod przysięgą oświadczenia zbywcy o przeniesieniu praw do nieruchomości i dokonania czynności o charakterze symbolicznym, który oznaczać miał wydanie zbywanej rzeczy, np. poprzez włożenie nabywcy czapki na głowę, wręczenie rękawiczki lub zielonej gałązki.

Umowy dotyczące przeniesienia praw własności ziemskiej zawierane były na piśmie już ok. 1000 roku $^{3}$. Sam fakt spisania umowy sprzedaży nie stanowił wystarczającej przesłanki do przeniesienia praw rzeczowych na nabywcę. Aby czynność ta mogła być uznana za skuteczną, należało nadać jej charakter publiczny, związany z udziałem świadków mogących wnieść zastrzeżenia, co do legalności praw posiadanych przez sprzedającego, którzy w razie konieczności mieli zaświadczać o zaistniałym zdarzeniu.

Z dokumentów archiwalnych wynika, że już w XIII w. warunkiem skutecznego nabycia prawa własności była konieczność spisania aktu i potwierdzenia go przez księcia. W okresie XIV-XV w. umowy przeniesienia praw do posiadłości zawierane były także bezpośrednio przed sądami, ale i wówczas

${ }^{1}$ Element wydania rzeczy przy jej sprzedaży, jako warunek skuteczności dokonanej czynności przeniesienia własności, wynikał z obowiązującej w wielu krajach europejskich rzymskiej zasady traditio.

${ }^{2}$ Por. J. Bardach, Historia państwa i prawa Polski, Warszawa 1964, s. 299.

${ }^{3}$ Por. J. Bardach, op. cit., s. 229; por. J.W. Bandtke-Stężyński, Historya prawa polskiego, Warszawa 1850, s. 224. 
czynność alienacji wymagała potwierdzenia przez księcia ${ }^{4}$ Czynność wwiązania, aby mogła być uznana za skuteczną, wymagała spełnienia ustalonych prawem zwyczajowym (intromissio licita) norm, w tym opierać się na tytule prawnym (umowa stron, wyrok sądowy, spadek itp.). Sprzedający powinien dysponować zbywanym prawem, a także zdolnością prawną, a sama czynność przebiegać $\mathrm{w}$ formie prawem przewidzianej. Wwiązanie (intromissio) jako sposób wprowadzenia nowego nabywcy w posiadanie dóbr ziemskich było jawne i odbywało się w obecności miejscowej władzy, zwykle woźnego (lub podsędka ziemskiego) oraz dwóch przedstawicieli szlachty, a także osób bezpośrednio tym zainteresowanych. Alienacja dokonana bez udziału przedstawicieli władzy podlegała karze sądowej. W czynnościach wwiązania uczestniczył zbywca prawa (ustępujący), którego obowiązkiem było wprowadzenie nabywcy w posiadanie chyba, że z zawartej umowy wynikało wprost, iż może być ona dokonana podczas jego nieobecności. Przyjęte prawo zwyczajowe wymagało, aby w czynnościach wwiązania, podczas obchodu i wskazywania przebiegu granic przejmowanych gruntów uczestniczyli wszyscy właściciele sąsiadujących posiadłości ziemskich. Podczas obchodu mieli oni sposobność zgłosić swoje zastrzeżenia, co do położenia kopców granicznych i przebiegu granic. Osoby, które nie zgłosiły uwag co do przebiegu granic lub nie stawiły się na gruncie, pomimo prawidłowego zawiadomienia, i w terminie 3 lat i 3 miesięcy nie podniosły stosownych zarzutów, zgodnie ze statutem wartskim z 1423 r. (art. 12) traciły prawo do skutecznego dochodzenia roszczenia w tym zakresie (nie był dopuszczone do dowodu) ${ }^{5}$. Według średniowiecznego prawa zwyczajowego, które zanikło ok. XV w., nowy posiadacz gruntów, aby potwierdzić swoje uprawnienia do nabytej ziemi, musiał przez trzy dni pozostawać na tym gruncie (mansio triduana in fundo) ${ }^{6}$.

Wprowadzenie w posiadanie nabywcy nieruchomości łączyło się z koniecznością tzw. wywiązania dotychczasowego posiadacza, która to czynność zwana była także zastąpieniem albo wyprowadzeniem (resignatio). Poprzedniemu właścicielowi pozostawiano czas niezbędny do przekazania posiadłości nowemu nabywcy. Akt wywiązania przebiegał według ustalonej zwyczajem formuły, w trakcie której zainteresowane strony przekazywały sobie rzecz będącą przedmiotem umowy. Czynność wwiązania miała charakter symboliczny i ograniczała się do publicznego wręczenia nabywcy przedmiotów kojarzonych powszechnie $z$ władzą, np. poprzez wręczenie czapki, płaszcza czy zielonej gałązki. Innym symbolem wywiązania było tzw. zeskakiwanie z gruntu.

${ }^{4}$ K. Dunin, Dawne mazowieckie prawo, Warszawa 1880, s. 160-161.

${ }^{5}$ A.Z. Helcel, Starodawne prawa polskiego pomniki, Kraków 1856, t. I, s. 316; P. Dąbkowski, Prawo prywatne polskie, Lwów 1911, t. II, s. 193-195; por. S. Łaguna, O prawie granicznem polskiem, Warszawa 1858, s. 23.

${ }^{6}$ P. Dąbkowski, Prawo prywatne..., t. II, s. 195-196; por. P. Dąbkowski, Zasada jawności w dawnem prawie polskiem, Lwów 1937, s. 2. 
Na znak zrzeczenia się własności pito wodę lub miód. Czynność wwiązania stanowiła niezbędny element skutecznego nabycia własności. Tytuł prawny do posiadłości ziemskiej, który istniał przez określony czas, ale bez dokonanej czynności wwiązania się i ujawnienia w księgach ulegał zatarciu, co oznaczało, że każdy, kto posiadał pewne prawa do nieruchomości, ale nie objął jej w posiadanie w przeciągu trzech lat tracił je „na zawsze”. Osoba, która nabyła pewne prawa do nieruchomości, ale nie objęła ich w posiadanie w przeciągu 10 lat, traciła swoje prawa przez dawność 7 .

Wraz z rozwojem na terenach polskich rejestrów urzędowych prowadzonych w sądach, ale także na dworach książęcych, znaczenie sporządzonych „prywatnych” dokumentów jednak malało. Większą wagę zaczęły mieć dokumenty wydawane bezpośrednio przez kancelarie rejestrowe książąt (np. Metryka Koronna lub Metryka Mazowiecka) lub udostępniane z rejestru zapadłych orzeczeń lub czynności dokonanych bezpośrednio przed sądem ${ }^{8}$. $\mathrm{W}$ miastach prawa dotyczące nieruchomości rejestrowane były w księgach sądowych prowadzonych przy radach miejskich i sądach wójtowsko-ławnicznych, zaś na terenie wsi w wiejskich księgach sądowych ${ }^{9}$.

W prowadzonych wówczas ,regestrach sądowych" (tabulae iudicii) ${ }^{10}$ były odnotowywane wzmianki o dokonanych przed sądem aktach sprzedaży gruntów, tzw. wzdaniach (resignatio), które traktowane jako oświadczenia dotychczasowych właścicieli o wyzbyciu się posiadanego prawa na rzecz wskazanego nabywcy, miały zastąpić tzw. „instytucję wsteczy”, polegającą na uzgadnianiu z sędziami faktu wcześniejszego złożenia przed nimi oświadczeń, dotyczących wyzbycia się praw do wskazanej rzeczy ${ }^{11}$. W rejestrach tych, co ciekawe, odnotowywano również wyroki sądów rozstrzygające spory graniczne czy ustanowione na nieruchomości prawa rzeczowe o charakterze zabezpieczającym, np. w zakresie zastawu czy hipoteki. Tak prowadzone księgi grodzkie nabyły z czasem prawo do zamieszczania w nich tzw. wpisów o charakterze wieczystym ${ }^{12}$. Nie wymagały bowiem one - do uzyskania mocy dowodowej ujawnionego w nich wpisu - jego potwierdzenia na podstawie dokumentu wydanego z innego rejestru, np. ziemskiego. Podkreślić należy jednak, że brak ujawnionego wpisu w księgach grodzkich potwierdzającego posiadanie praw do określonej nieruchomości nie stanowił formalnej przeszkody uniemożliwiającej skuteczne przeniesienie prawa własności i doko-

${ }^{7}$ Ibidem, s. 197-198.

${ }^{8}$ T. Stawecki, Rejestry nieruchomości, księgi hipoteczne i księgi wieczyste od czasów najdawniejszych do XX wieku, t. XL, „Studia Iuridica” 2002, s. 178.

${ }^{9}$ W. Wojcikiewicz, Prawo hipoteczne Krolestwa Polskiego, Wrocław-Warszawa-Kraków, 1967, s. 19.

${ }^{10}$ Pierwsze wzmianki o nich pochodzą w Polsce z 1322 r. - por. T. Stawecki, Rejestry publiczne. Funkcje instytucji, Warszawa 2005, s. 373-374.

${ }^{11}$ Por. A. Menes, Wiadomości wstępne dotyczace ksiag wieczystych, „Rejent” 1994, nr 4, s. 58.

${ }^{12}$ Takie uprawnienia nabyły w XV wieku księgi prowadzone przez grody wielkopolskie. 
nane na tej podstawie tzw. wwiązania prowadzącego do intromisji nabywcy. W takich przypadkach zbywca musiał obowiązkowo potwierdzić swoje prawa do sprzedawanej nieruchomości w obecności świadków ${ }^{13}$. Czasem w czynnościach objęcia nieruchomości w posiadanie, składających się z aktu rezygnacji i wwiązania, które zwane były w warunkach polskich tradycją ${ }^{14}$, odpowiadających instytucji rzymskiego traditio, uczestniczył także woźny sądowy, którego zadaniem było złożenie relacji z tego zdarzenia w aktach sądowych.

Z upływem czasu czynność przeniesienia prawa do nieruchomości, składająca się z aktu rezygnacji i wwiązania, zastąpiona została jednym oświadczeniem stanowiącym rodzaj pokwitowania zaspokojenia należności, w ramach której sprzedający składał oświadczenie nabywcy, że nieruchomość stanowiąca przedmiot kontraktu pozostaje jego własnością w oznaczonym obszarze, a także określał sumę gwarantowaną, zwaną ewikcją, która stanowić miała rodzaj finansowego zabezpieczenia zawartej umowy na czas 3 lat i 3 miesięcy. Jeżeli w okresie tym nie wyszły na jaw wady prawne lub nabywca nie zgłosił zarzutów, ewikcja wygasała ${ }^{15}$. Istotną częścią umowy przeniesienia prawa własności stanowiło często oświadczenie sprzedającego, w którym udzielał on kupującemu rękojmi na wypadek, gdyby ktokolwiek kwestionował jego tytuł do nabytej posiadłości. Zbywający prawo własności zobowiązywał się tym samym do niezwłocznego przystąpienia (na podstawie zawiadomienia osoby zainteresowanej) do procesu sądowego, którego przedmiotem było ustalenie praw do sprzedanej przez niego posiadłości ziemskiej. Udzielona rękojmia trwała do czasu upływu okresu przedawnienia, tj. 3 lat ${ }^{16}$.

\section{Księgi gruntowe jako systemowy element rzeczowego zabezpiecze-} nia wierzytelności. Rozwój wymiany handlowej i wprowadzenie do obiegu pieniądza spowodowało, że majątek ziemski zaczął pełnić także funkcję rzeczowego zabezpieczenia udzielanych kredytów. W początkowym okresie praktykowany był zwyczaj zabezpieczenia wierzytelności $\mathrm{w}$ formie zastawu połączonego z posiadaniem (inscriptio obligationis de facto), a dopiero następnie usankcjonowano formę zastawu, na mocy którego wierzyciel mógł obciążone dobra przejąć (dokonać zajazdu), gdy należna kwota w umówionym terminie nie została mu wypłacona (inscriptio certi debiti ad tempus certum obligati $)^{17}$. Dług ujawniony w księgach na majątku dłużnika dawał pierwszeństwo zaspokojenia wierzycielowi przed późniejszymi długami.

${ }^{13}$ Por. T. Stawecki, Rejestry nieruchomości..., s. 179.

${ }^{14}$ Używano także innych określeń takich jak: introductio, introgatio, inequitatio.

${ }^{15}$ W. Wójcikiewicz, op. cit., s. 22; por. K. Dunin, Dawne mazowieckie..., s. 173.

${ }^{16}$ Wśród ludów słowiańskich powszechnie przyjmowany był trzy letni termin przedawnienia, co prawdopodobnie wynikało s trójpolowego systemu uprawy roli - por. K. Dunin, Dawne prawa..., s. 163.

${ }^{17}$ W. Dutkiewicz, Prawo hipoteczne, Warszawa 1850, s. 2. 
Na mocy statutu z $1401 \mathrm{r}$. każdy wierzyciel posiadał uprawnienie do wystąpienia $\mathrm{z}$ żądaniem zabezpieczenia swoich praw w postaci ustanowienia zastawu na posiadłości ziemskiej. Ilościowy sposób określenia tego zastawu określony został w statucie z 1496 r., w którym oznaczono ilość ziemi, jaką należało oddać w zastaw wierzycielowi w zamian za pożyczoną jednostkę pieniężną. Za każdą pożyczoną kopę należało zastawić taką wielkość roli, na której można było wysiać korzec żyta albo łąki, z której można zebrać dwa wozy jednokonne siana. Po ujawnieniu zastawu w księgach ziemskich uprawniony wierzyciel „wwiązywał się" w zastawione dobra, co łączyło się z uprawnieniem do użytkowania i pobierania pożytków (dochodów) z zastawionej rzeczy.

Stosowano dwa rodzaje zastawu, tzw. zastaw ,prosty” i ,pod przypadkiem" (inseriptio lapsus perpetni, obligatio sub lapsu), z których ten drugi stanowił formę sprzedaży nieruchomości z prawem odkupu ustanowionym na określony czas (pactum de retro vendendo). Zgodnie z przyjętym zwyczajem ostateczny termin wykupu zastawionych gruntów odpowiadał terminowi przedawnienia i w zależności od regionu wynosił na mazowszu odpowiednio 3 lata $^{18}$ lub 1 rok i 6 niedziel ${ }^{19}$. Od 1531 roku terminy te liczone były od chwili wwiązania się nabywcy (wierzyciela) w posiadanie majątku podlegającemu retraktowi (wykup), tj. prawu bliższości wynikającemu z pokrewieństwa, na podstawie którego pragnący skorzystać z tego uprawnienia zobowiązany był, w przypadku alienacji tych gruntów, zwrócić zastawnikowi sprawiedliwą cenę (justa pecunia). Wierzyciel, który przejął majątek swego dłużnika mógł dokonać jego alienacji dopiero z chwilą, gdy uprawnieni krewni nie skorzystali z prawa do retraktu (wykupu). Prawa krewnych do przejętego przez wierzyciela majątku rodowego mogły się zatem spełnić jedynie wówczas, gdy dobra te aktualny właściciel sprzedawał lub zastawiał za równowartość kwoty oferowanej przez kupującego lub biorącego w zastaw. Zastaw prosty stanowił natomiast formę bezterminowego zabezpieczenia majątkowego, w ramach którego dłużnik mógł w każdym czasie spłacić swoje zobowiązania i odebrać przedmiot zastawu, wzywając w tym celu swojego wierzyciela do sądu ${ }^{20}$.

Wedle ustawodawstwa Kazimierza Wielkiego każdy, kto zastawił swoje dobra ziemskie, aby nie utracić prawa do ich wykupu w okresie 30 lat, zobowiązany był corocznie podczas wiecu publicznego obwieścić, w jakiej wysokości dobra jego są obciążone (art. XXXIX). Osoba, która tego nie czyniła, traciła prawo do wykupu zastawionego majątku po upływie 15 lat $^{21}$.

${ }^{18}$ Zgodnie ze Statutem Ziemowita IV z 1390 r. - por. A.Z. Helcel, Starodawne prawa..., t. I, s. 277; por. K. Dunin, Dawne prawo mazowieckie, Warszawa 1880, s. 157.

${ }^{19}$ Na podstawie Statutu Ziemowita IV z 1387 r. - por. A.Z. Helcel, Starodawne prawa ..., t. II, s. 275-276.

${ }^{20}$ K. Dunin, Dawne prawo..., s. 179-180.

${ }^{21}$ Por. A.Z. Helcel, Starodawne prawa ..., t. I, s. 82. 
Pierwsze udokumentowane wzmianki dotyczące zastosowania na ziemiach polskich instytucji zastawu bez dzierżenia (zabezpieczeń obligacyjnych) odnaleźć można już w XIII wieku, w zapiskach kończących spór o dziesięciny klasztoru Cystersów w Sulejowie i Premonstratów w Witowie. W zawartym porozumieniu w 1282 r., przy udziale legata Stolicy Apostolskiej Filipa, strony umowy zabezpieczały wykonanie kontraktu „pod karą dwóch grzywien złota na obecnych i przyszłych swoich majątkach”. Innym przykładem zastosowania tej instytucji prawa może być zabezpieczenie pożyczki w wysokości 30 grzywien, udzielonej przez biskupa wrocławskiego Gerwarda proboszczowi zakonu Promonsteratek w Strzelinie w 1312 r., na okres spłaty 4 lat, w postaci majątku Złotowo, pod rygorem jego przejścia na własność wierzyciela w przypadku gdyby spłata nie nastąpiła ${ }^{22}$.

Jak podaje $\mathrm{O}$. Balzer, ta forma zabezpieczenia wierzytelności pieniężnych (zastaw bez dzierżenia) rozpowszechniła się w Europie w XIII w., a na ziemiach polskich stosowana była powszechnie z końcem XIV wieku ${ }^{23}$. Już za czasów Kazimierza Wielkiego w Statucie Wiślickim z 1347 r. wprowadzono zasadę jawności publicznej dla wszelkich zastawów obciążających majątki ziemskie, ,a wszystko to po to, by nikt nie doznał zawodu z przyczyny pożyczenia pieniędzy pod zastaw majątkowy"24.

W tym okresie wykształciła się zasada zobowiązująca strony kontraktu do sporządzania aktu alienacji w formie pisemnej i obowiązku zarejestrowania go we właściwej miejscowo księdze sądowej, czego przykładem mogą być księgi kancelarii miejskiej krakowskiej zawierającej zapiski z lat 1360-1375, czy też księgi ziemi kujawskiej pochodzące z $1381 \mathrm{r}^{25}$

Instytucja hipoteki postrzegana jako szczególny rodzaj zastawu umownego (zastaw bez dzierżenia) ${ }^{26}$, w ramach której obciążona umową nieruchomość pozostawała w rękach dłużnika, który mógł nią dysponować, pozyskując w ten sposób środki na spłatę wierzytelności, przyczyniła się do rozwoju rejestrów gruntowych w całej Europie. Zapisanie prawa własności do nieruchomości w urzędowym rejestrze (księgach sądowych) służyć miało nadaniu aktowi prawnemu alienacji cech trwałości (wieczystej) i dawać właścicielowi gwarancję ochrony tak ujawnionych praw, a wierzycielom pewność zabezpieczenia ich interesów.

Instytucja hipoteki, a precyzyjniej rzecz definiując kontraktu hipotecznego zwanego obligatio in bonis assecurata, pojawiła się w prawie polskim

22 Por. A. Parczewski, Rys historyczny hipoteki polskiej, „Gazeta Sądowa Warszawska” 1918, nr 43-45, s. 417.

${ }^{23}$ Por. O. Balzer, Hipoteka $w$ dawnym ..., s. 476.

${ }^{24}$ K. Józefowicz, Przepisy o hypotekach, Warszawa 1873, s. 6.

${ }^{25}$ Por. O. Balzer, Hipoteka w dawnym..., s. 477; por. W. Wójcikiewicz, op. cit., s. 16; por. K. Dunin, Dawne prawo..., s. 160-163.

${ }^{26}$ Por. K. Sójka-Zielińska, Historia prawa, Warszawa 2005, s. 148. 
wraz z księgami ziemskimi i grodzkimi na przełomie XV i XVI w. ${ }^{27}$ i wprowadziła, w odróżnieniu od hipoteki rzymskiej, zasadę jawność wierzytelności obciążających przedmiot zabezpieczenia (nieruchomość). Na mocy zawartego kontraktu hipotecznego wierzyciel uzyskiwał gwarancję bezpieczeństwa wierzytelności zabezpieczonych na majątku rzeczowym z pierwszeństwem jego egzekucji, pod warunkiem jego ujawnienia w aktach wieczystych właściwych in foro proprii districtus (z uwagi na właściwość miejscową urzędu rejestrowego - tzw. położenie w dobrach pozwu). Położenie w tzw. dobrach pozwu dawało zainteresowanemu prawo do egzekucji z majątku swojego dłużnika po wcześniejszym uzyskaniu zasądzenia należnej mu wierzytelności (lucri). Zastawnik (posiadacz), który nie chciał dopuścić do egzekucji ze swego majątku, winien w przeciągu jednego roku wystąpić z żądaniem zniesienia złożonego przez wierzyciela pozwu, dowodząc, że wypełnił on swoje wobec niego zobowiązania ${ }^{28}$.

W 1496 r. Jan Olbracht wprowadził prawo, zgodnie z którym ,wszelkie inskrypcje ujawnione $\mathrm{w}$ księgach grodzkich, w przeciągu jednego roku do właściwych miejscowo ksiąg ziemskich winny być przeniesione"29. Zapisany w księgach ziemskich akt przeniesienia lub ustanowienia prawa uzyskiwał w ten sposób cechę wiecznej trwałości (perpetuitatem), a dług tak zapisany nie podlegał przedawnieniu. Aby uzyskać prawo rzeczowe do nieruchomości, niezbędnym było dokonanie wpisu $\mathrm{w}$ księgach ziemskich i posiadanie oryginalnego tytułu. Jeżeli właściciel swego prawa nie ujawnił we właściwych księgach ziemskich ${ }^{30}$, to po upływie roku i 6 tygodni prawo to wygasało.

Średniowieczne rejestry nieruchomości, wśród których wymienić można polskie księgi ziemskie i grodzkie, niemieckie księgi miejskie i gruntowe, w północnej Francji rejestry sądowe, czy też angielskie księgi saqdowe, postrzegane były jako instytucje prawa, za pomocą których państwo posiadało w pewnym zakresie możliwość kontrolowania czynności cywilnoprawnych dotyczących przenoszenia praw do nieruchomości, gwarantując przy tym jawność formalną stosunków prawno-rzeczowych dotyczących nieruchomości. Prowadzone księgi koncentrowały się przede wszystkim na rejestrowaniu i identyfikowaniu osób, którym przysługiwały określone prawa rzeczowe, oraz wykazywaniu obciążeń na nich ustanowionych, w mniejszym stopniu zwracając uwagę na opis samego przedmiotu tych praw (działek gruntowych). Intensywny rozwój rejestrów nieruchomości (ksiąg wieczystych) datowany jest z chwilą rozpowszechnienia wymiany handlowej opartej na sile nabywczej

${ }^{27}$ O. Balzer, Hipoteka $w$ dawnym..., s. 476.

${ }^{28}$ W. Dutkiewicz, op. cit., s. 3; por. K. Dunin, Dawne prawo..., s. 169.

${ }^{29}$ Vol. leg. T. I, s. 118.

${ }^{30}$ Według art. 13 statutu wareckiego z 1420 r. księgi ziemskie przechowywane były ,pod trzema kluczami”, z których jeden przechowywał sędzia, drugi podsędek, a trzeci pisarz ziemski. Księgi mogły być otwierane i przeglądane jedynie przy udziale tych osób. 
pieniądza, rozwoju instytucji kredytu realnego i koniecznością jego majątkowego zabezpieczenia $\mathrm{w}$ formie hipoteki ${ }^{31}$.

III. Oznaczanie granic własności. Podobnie jak w innych rejonach średniowiecznej Europy, granice poszczególnych własności ziemskich oznaczane były w średniowiecznej Polsce dużymi kamieniami granicznymi, które - usytuowane na miedzach - stanowić miały wyraźne i trwałe znaki rozdzielające sąsiednie posiadłości ziemskie. Na kamieniach granicznych dodatkowo umieszczono, w celu ich ochrony przed zniszczeniem, wyciosany wizerunek ukrzyżowanego Chrystusa lub inicjały jego imienia.

Innym sposobem oznaczania granic własności był zwyczaj sypania „kopców", które, usytuowane w punktach zejścia trzech lub więcej własności, zwane były „węgielnikami” (scopulus angularis) lub kopcami „ściennymi” (parietalis).

W punktach granicznych sadzono czasem drzewa, w szczególności wierzby lub grusze, na których umieszczano widoczne znaki graniczne (naciosy) ${ }^{32}$ w postaci krzyża lub innego ,piętna”. Zwyczaj sadzenia gruszy w miejscach wyznaczających granice własność wynikał jeszcze ze starych wierzeń, według których jej ścięcie sprowadzało nieszczęście na człowieka, który tego dokonał. Grusza, stanowiąca znak graniczny, przestrzegać zatem miała każdego, kto chciałby ją usunąć, w szczególności, że - jak podaje cytowany autor - „gwałtowników granic wieszano".

Każdy mógł odróżnić kopiec graniczny od innego naturalnego pagórka, ponieważ obkładano je dodatkowo węglem ${ }^{33}$, potłuczoną ceramiką, szkłem itp., co miało stanowić czytelny znak, że są to kopce usypane umyślnie, wyznaczające punkty graniczne. Celem udokumentowania tych czynności obecnych przy tym „młodzieniaszków” układano na tak przygotowane kopce i wymierzano im ,,po kilka plag, żeby na całe życie znak graniczny zachowali w lepszej pamięci" 34 . Osoby te, podczas urzędowego obchodzenia granic (zwanym „ochodzą”), miały świadczyć w przyszłości o prawidłowym położeniu znaków wyznaczonych przy ich udziale.

Czynność tzw. obchodzenia w pierwszym okresie jej praktykowania (XII w.) była dokonywana przez samego księcia lub jego namiestnika, a w późniejszym czasie - podkomorzego. $Z$ dokonanych oględzin sporządzany był szczegółowy opis przebiegu granic, który - w przypadku sporu granicznego - stanowił dowód w sprawie, a także potwierdzał granice własności przy ich sprzedaży.

${ }^{31}$ Por. J. Wasilkowski, Prawo rzeczowe $w$ zarysie, Warszawa 1957, s. 316; por. O. Balzer, Hipoteka w dawnym ustawodawstwie polskim, GSW 1888, nr 29, s. 475.

${ }^{32}$ Ibidem.

${ }^{33}$ Stąd też wzięła się nazwa węgielników.

${ }^{34}$ Por. A. Korwicki, Proces graniczny, Wilno 1827, s. XIX. 
Podczas objazdu nadawanych majątków ziemskich książę nakazywał ustawiać znaki graniczne we wskazanych przez siebie miejscach, które miały wyznaczać ich obszar, czego przykładem może być Bolesław Wstydliwy, który w 1254 r. wyznaczył w ten sposób dobra klasztoru w Krzyżanowicach ${ }^{35}$.

W rozumieniu ówczesnego prawa, w skład majątku ziemskiego - oprócz siedziby posiadacza - wchodziły także przynależności (pertinentiae), czyli łączące się z nią części tworzące jedną całość, którymi były: wszystkie pola uprawne i nieuprawne, łąki, zarośla, las, i wszystko, co jest zawarte w granicach dziedziny i z nią połączone (zwane czasem prawem przynależności włości), a także wszelkiego rodzaju wody, o ile stanowią własność prywatną, a także błota. Cechą przynależności było to, iż mogła ona stanowić odrębną własność, lecz tylko z uwagi na istniejące powiązania prawne stanowiła przynależność do rzeczy głównej.

$\mathrm{W}$ aktach nadania posiadłości ziemskich granice (termini, metae) określające zasięg prawa własności były zaliczane do przynależności majątku ziemskiego, a wyznaczone na gruncie, na podstawie zamieszczonego w akcie ich opisu, miały stanowić zabezpieczenie spokojnego ich użytkowania, czego przykładem może być opisany w literaturze przypadek z 1280 r., kiedy Świętosław, dziedzic Żelechowa, upraszał księcia krakowskiego Bolesława, aby ten polecił jego dziedzinę od posiadłości książęcej Klyz odgraniczyć i oznaczyć $^{36}$.

IV. Księgi gruntowe i zasady ich prowadzenia w okresie od XVI wieku do czasu rozbiorów Polski. Za panowania Zygmunta Augusta przeprowadzona została, w dobrach wielkoksiążęcych na Litwie i Żmudzi, a także na Podlasiu ${ }^{37}$ reforma rolna, zwana ,pomiarem włócznym”, polegająca na podziale gruntów w zależności od ich przeznaczenia na jednostki rejestrowe (włóki), dla których założone zostały rejestry pomiarowe i mapy stanowiące podstawowy dokument umożliwiający ustalenie stanu własności jak i rozgraniczania nieruchomości ${ }^{38}$. Dokumenty te wykorzystywane były aż do czasów przeprowadzenia akcji katastralnej na przełomie XVIII/XIX w., będącej bezpośrednim skutkiem likwidacji na ziemiach polskich pańszczyzny i uwłaszczenia chłopów. Nowa sytuacja społeczna wymusiła na władzy przeprowadzenie reformy podatku gruntowego i oparcie go na pomiarach geodezyjnych, jednolitej klasyfikacji gruntów oraz rejestrach gruntowych.

Znaczenie prowadzonych ksiąg gruntowych, w których rejestrowane były prawa do nieruchomości, uległo formalnemu wzmocnieniu z chwilą przyjęcia

${ }^{35}$ Por. S. Łaguna, O prawie granicznem polskiem, Warszawa 1858, s. 9.

${ }^{36}$ Por. R. Hube, Prawo polskie w wieku trzynastym, Warszawa 1874, s. 104-105.

${ }^{37}$ Za panowania królowej Bony.

${ }^{38}$ J. Andrzejewski, A. Krygier, W. Sztukiewicz, Kataster gruntowy w Wielkopolsce - historia i teraźniejszość, „Przegląd Geodezyjny” 1995, nr 11, s. 17-20. 
w 1588 r., podczas Sejmu koronacyjnego Zygmunta III, Konstytucji zawierającej ustawę „o ważności zapisów”39. Należy podkreślić, że zapisane tam systemowe rozwiązania wprowadzające do porządku prawnego instytucję polskiej hipoteki (choć wówczas nie nazwaną) ${ }^{40}$ wyprzedzały, w tym zakresie prawie o dwa wieki ustawodawstwo większości państw zachodniej Europy ${ }^{41}$. Nowoczesność uchwalonej ustawy polegała na zdefiniowaniu i przyjęciu, jako normy powszechnie obowiązującej zasady jawności formalnej i materialnej hipoteki, legalności hipoteki, swobody obciążania hipotecznego, szczegółowości czy pierwszeństwa wpisu, a także zasady dobrej wiary ksiąg rejestrowych ${ }^{42}$.

Uchwalone normy ustalające jawność hipoteki, wymuszały tym samym konieczność utworzenia i prowadzenia ksiąg publicznych (sądowych, grodzkich, ziemskich), w których rejestrowane byłyby prawa rzeczowe obciążające zidentyfikowaną nieruchomość. Ustawa o ważności zapisów wprowadzała obowiązek ustanowienia prawa rzeczowego, w szczególności wynikającego z zawartego kontraktu bezwarunkowego kupna nieruchomości, umowy warunkowej z prawem odkupu zastawu czy też innych tego rodzaju umów, przed właściwym miejscowo sądem z zachowaniem ustalonej formy zeznania (recognitio) lub sądowego przyznania (roboratio).

Prowadzone księgi urzędowe gwarantować miały każdemu zainteresowanemu, działającemu w zaufaniu do treści ujawnionych wpisów, ochronę prawną, dając pierwszeństwo wpisom istniejącym nad prawami w niej nieujawnionymi, w tym chronić nabywcę działającego w dobrej wierze oraz stanowić realne zabezpieczenie dla wierzyciela przed utratą jego należności. Bezpodstawne podważanie wiarygodności wpisów w księgach grodzkich czy ziemskich chronione było sankcjami karnymi w postaci 6 tygodni wieży ${ }^{43}$.

Przyjęta zasada legalizmu ustanawiała zaś regułę, że wpis do prowadzonych ksiąg publicznych możliwy był jedynie na wyłączny wniosek osoby, której prawa ujawnione były w rejestrze po jego wcześniejszym zbadaniu przez organ prowadzący księgi. W przypadku obciążenia nieruchomości hipoteką, osobą uprawnioną do dokonania wpisu w księgach właściwych ze względu na miejsce położenia obciążanej nieruchomości, winien być zatem sam zainteresowany dłużnik, a nie osoby trzecie lub ich pełnomocnicy ${ }^{44}$.

${ }^{39}$ Vol. leg. II, s. 258 (art. 28, poz. 1220).

${ }^{40}$ W. Dutkiewicz, op. cit., s. 2; por. A. Parczewski, op. cit., s. 418.

${ }^{41} \mathrm{~Np}$. we Francji zasada jawności hipoteki wprowadzona zastała w ograniczonym zakresie dopiero w Kodeksie Napoleona; w prawie niemieckim zaś zasada pierwszeństwa rzeczowego wprowadzona została w XVIII w. - por. W. Wójcikiewicz, Prawo hipoteczne..., s. 29-30; por. K. Józefowicz, Przepisy o hypotekach, Warszawa 1873, s. 6. Ibidem.

${ }^{42}$ A. Parczewski, op. cit., s. 418.

${ }^{43}$ Od 1768 r. karę tę zwiększono do 12 tygodni - por. W. Wójcikiewicz, Prawo hipoteczne..., s. 28.

${ }^{44}$ O. Balzer, Hipoteka $w$ dawnym..., s. 479. 
Zasada szczegółowości wpisu wprowadzała natomiast ograniczenie prawne zawężające możliwość obciążenia hipoteką jedynie te nieruchomości, które wskazane zostały w złożonym wniosku, jako rzeczowe zabezpieczenie udzielonej pożyczki. Wpis w księdze winien precyzyjnie określać łączną sumę zabezpieczonych wierzytelności oraz sam przedmiot realnego zabezpieczenia, a wszystko to po to - jak zapisano w ustawie - aby „... ludzie nie zawodzili się pożyczając pieniądze super bona operata (na dobra obciążone)".

Przyjęte rozwiązanie wyeliminowało tym samym z praktyki poprzednio obowiązujące prawo dopuszczające możliwość ustanawiania tzw. hipoteki generalnej (wzorowanej na prawie rzymskim), która mogła obciążać wiele nieruchomości bez precyzowania, których majątków ona dotyczy. Zasada szczegółowości dopuszczała możliwość zabezpieczenia wierzytelności na wielu nieruchomościach ujawnionych w prowadzonych księgach publicznych, pod warunkiem jednak szczegółowego ich wskazania w złożonym wniosku o wpis hipoteki w księgach rejestrowych ${ }^{45}$.

Zasada pierwszeństwa (prior tempore potior iure) ${ }^{46}$ precyzowała z kolei, które z praw rzeczowych ujawnionych w prowadzonych księgach, obciążających daną nieruchomość mogą być realizowane przed innymi zobowiązaniami hipotecznymi. Kryterium rozstrzygającym o kolejności zaspokojenia wierzyciela z nieruchomości stanowiącej przedmiot zabezpieczenia stanowiła data wpisu we właściwej księdze, ustalająca moment powstania samego zobowiązania hipotecznego ${ }^{47}$. W przypadku wpisu do rejestru kolejnego obciążenia nieruchomości, wierzyciel hipoteczny posiadający prawo pierwszeństwa zobowiązany był zgłosić swoje roszczenia w przeciągu trzech lat od daty jego ujawnienia. Jeżeli tego nie uczynił, tracił swoje prawo na rzecz kolejnego uprawnionego wierzyciela. Jeżeli dłużnik nie wywiązał się ze swego zobowiązania, wierzyciel obejmował obciążoną hipoteką nieruchomość na podstawie wyroku sądowego. Zasada pierwszeństwa przejawiała się w szczególności w sytuacji, w której wartość obciążonej nieruchomości nie zabezpieczała w pełni łącznej sumy ustanowionych na niej zabezpieczeń (hipotek). Na specjalnej rozprawie (causa potioritas) sąd, wspólnie ze wszystkimi wierzycielami, ustanawiał kolejność ich zaspokojenia z nieruchomości dłużnika, odwołując się przy tym do obowiązującej zasady pierwszeństwa wpisu ${ }^{48}$.

${ }^{45}$ O. Balzer, Hipoteka w dawnym ..., s. 479; por. W. Wójcikiewicz, Prawo hipoteczne..., s. 28.

${ }^{46}$ Co znaczyło ,pierwszy czasem lepszy prawem”.

${ }^{47}$ „A prioritas tego zapisu ma bydź liczona od onego aktu, gdy będzie in proprio foro per oblatam aktywowany" - Vol. leg. II, s. 258.

48 „Trybunał suspensę z posessorem uczyniwszy, kompetitorem (to jest do jednych dóbr ubiegających) między sobą rozprawiać się nakazuje; w rozprawie tam się oni rugują, kto na tablicy zostać, kto z niej spaść; czyje prawo contra possessorem prima loco, albo też secundo lub tertio i dalej ma subsistere. Ten co się utrzymał (jus deterius mający), miał przywile spłacenia przed nim kollokowanych i objęcia tym sposobem dóbr, które to do lat 30 służyło" - por. W. Dutkiewicz, Prawo hipoteczne..., s. 9. 
Zasada dobrej wiary ksiąg, mająca swoje wcześniejsze odniesienie w Konstytucji sejmowej z 1507 r. de inscriptionibus bonorum in fraudem factis ${ }^{49}$, wyrażona była zaś w zapisie stanowiącym o tym, że w przypadku stwierdzenia dokonania wpisu w księgach, będącego wynikiem zmowy stron, osobom (wierzycielom), które w rezultacie tych działań poniosły szkodę, przysługiwało prawo zaskarżenia takiego wpisu do sądu ${ }^{50}$.

Zadaniem prowadzonych według właściwości miejscowej ksiąg publicznych było rejestrowanie praw do wyodrębnionej i oznaczonej nieruchomości oraz informowanie o stanie ustanowionych na niej realnych ciężarach. Zapis (inscriptio) hipoteczny mógł być skutecznie dokonany w księgach grodzkich lub ziemskich powiatu, w granicach którego położone były obciążane majątki ziemskie (wpis in proprio foro) z zachowaniem zastrzeżonej formy samego kontraktu, który wymagał jego potwierdzenia (zeznania) przed sądem (recognitio) lub wynikał bezpośrednio z sądowego przyznania (roboratio). Wpis ustanawiający rzeczowe zabezpieczenie udzielonego kredytu, dokonany przed niewłaściwym miejscowo urzędem ziemskim, mógł być za pomocą tzw. oblaty przeniesiony do ksiąg urządzonych dla obciążanej nieruchomości i dopiero $\mathrm{z}$ tą chwilą wywoływał skutek rzeczowy nabycia hipoteki ${ }^{51}$. W przeciwnym razie ujawnienie wpisu w księgach niewłaściwych wywoływało jedynie skutek obligacyjny ${ }^{52}$.

Uchwalone prawo ustanawiające możliwość dokonywania „oblaty” wzorowane było na wcześniejszej normie wprowadzonej jeszcze za czasów panowania Olbrachta, a zapisanej w Statucie piotrkowskim w 1496 r. ${ }^{53}$ Funkcjonowało ono do czasu uchwalenia Konstytucji w 1768 i 1775 r., które definitywnie wprowadziły obowiązek dokonywania wpisu do właściwych miejscowo ksiąg gruntowych, pod rygorem utraty ustanawianych roszczeń ${ }^{54}$.

Podkreślić należy jednak, że ustawa o ważności zapisów z 1588 r., uzależniająca możliwość stosowania zasady pierwszeństwa od aktywacji in proprio foro per oblatam, nie określiła granicznego terminu, w jakim ta czynność miała być dokonana, aby mogła być uznana za skuteczną. W tym zakresie stosowane były zasady ustalone jeszcze w statucie piotrowskim z 1496 r., wyznaczające termin jednego roku na dokonanie oblaty.

${ }^{49}$ Vol. leg. I, s. 164-165 (poz. 363).

${ }^{50}$ Vol. leg. II, s. 258 (poz. 1220).

${ }^{51}$ Czynność związana z obciążeniem nieruchomości dokonana przed właściwym miejscowo sądem zwana była recognittio, natomiast czynność przeniesienia do sądu właściwego miejscowo ze względu na położenia obciążanej nieruchomości określana była, jako roboratio - por. W. Wójcikiewicz, Prawo hipoteczne..., s. 26; por. W. Dutkiewicz, Prawo hipoteczne..., s. 7.

${ }_{52}$ O. Balzer, Hipoteka w dawnym..., s. 477; por. K. Józefowicz, Przepisy o hypotekach..., s. 7.

${ }^{53}$ Statut piotrkowski z 1496 r. nakazywał przeniesienie w przeciągu roku wpisu dokonanego w niewłaściwych księgach grodzkich do ksiąg właściwych miejscowo ziemskich, pod rygorem nieważności zapisów - por. Vol. leg.I, s. 118; por. K. Józefowicz, Przepisy o hypotekach..., s. 6.

${ }^{54}$ Ibidem. 
Terminy te dookreślone zostały dopiero w konstytucji z 1768 r., w której zapisano, że czynność oblaty winna być dokonana $\mathrm{w}$ przeciągu jednego roku od daty ujawnienia w księgach niewłaściwych (ze względu na położenie przedmiotu kontraktu) transakcji wieczystych ${ }^{55}$, transakcji doczesnych (ręcznych) ${ }^{56}$, dożywocia czy zapisu, a w czasach niepokoju w ciągu roku i 6 tygodni od daty ustania tych przyczyn ${ }^{57}$. Przyjęte w 1768 r. rozwiązania prawne dotyczące rejestrów hipotecznych służyć miały, w zamiarze ich pomysłodawców, udoskonaleniu zasad uchwalonych w ustawie o ważności zapisów z 1588 r., i podyktowane były koniecznością zabezpieczenia interesów wierzycieli w związku z nagminną praktyką udzielania kredytów realnych ponad szacunkową wartość nieruchomości, stanowiących przedmiot zabezpieczenia długu. Jednym z pozytywnych zapisów ustawy z 1768 r., pozwalających ustalić realne i faktyczne obciążenie nieruchomości, było doprecyzowanie samego terminu dokonania czynności oblaty, co służyć miało wyeliminowaniu poczucia niepewności co do skuteczności dokonanych czynności dotyczących zabezpieczenia realnego na wskazanej przez dłużnika nieruchomości. Wpis dokonany w księdze niewłaściwej powodował bowiem, iż trudno było ustalić rzeczywiste obciążenie nieruchomości dłużnika, i przeprowadzenie wiarygodnej kwerendy ksiąg, w których ujawnione były obciążane nieruchomości, co miało niekorzystny wpływ na pewność w obrocie gospodarczym. Sankcją za niedotrzymanie określonych w ustawie (1768) terminów dokonania czynności oblaty była utrata mocy prawnej wpisu w niewłaściwej księdze, co powodowało, że umowa, pozostając ważną, nie wywoływała skutku w postaci np. realnego zabezpieczenia udzielonego kredytu, lecz określała jedynie zobowiązanie (skutek obligacyjny) pomiędzy stronami kontraktu ${ }^{58}$.

Przyjęte w Konstytucji z 1768 r. założenia zmierzające do utworzenia dla każdej nieruchomości unikatowych ksiąg urzędowych, w których rejestrowane miały być łącznie zarówno prawa, jak i realne obciążenia majątkowe, nie zostały jednak zrealizowane, a wprowadzone ograniczenie dotyczące swobody obciążenia nieruchomości dodatkowo spowodowały, że rozwiązana te uwsteczniły poprzednio obowiązujące prawo uchwalone w $1588 \mathrm{r}$.

55 Transakcje wieczyste, to w rozumieniu ustawy z 1768 r. umowy (kontrakty) przeniesienia własności (alienacji) zwane w konstytucji z 1588 r. inscriptio, do których zaliczano także prawo zastawu ustanowione na 30 lat.

${ }^{56}$ Transakcje doczesne (ręczne), to w rozumieniu ustawy z 1768 r., wszelkie czynności prawne nie zawierające w spbie aktu alienacji, w szczególności różnego rodzaju długi (wpisy hipoteczne).

57 „Tranzakcye wszelkie tak wieczyste jako i doczesne, ręczne dożywocia y zapisy w obcych grodach z ziemstwach zeznane, a podług pomienionego statutu na pierwszych lub powtórnych rokach, w czasie pokoju sposobem oblaty do xiąg własnego województwa lub powiatu gdzie się dobra znajdują, a w czasie niepokoju lub grassującego powietrza, po uspokojeniu tego w rok y niedziel sześć nie będą przeniesione, takowe tranzakcye niszczemy, y za nieważne w każdem sądzie mieć chcemy" - Vol. leg. T. 7., s. 331; por. W. Dutkiewicz, Prawo hipoteczne..., s. 12.

${ }^{58}$ W. Wójcikiewicz, Prawo hipoteczne..., s. 30-31; por. W. Dutkiewicz, Prawo hipoteczne..., s. 14 . 
Z tego też m.in. powodu w 1775 r. Sejm przyjął ustawę wprowadzającą podwójny system ksiąg wieczystych, zwanych protokołami. W jednym protokole ewidencjonowane były wszelkie obciążenia dotyczące dóbr, w tym zobowiązania osobiste i weksle, natomiast drugi miał służyć rejestrowaniu zapisów o innym charakterze ${ }^{59}$. Na mocy przyjętej ustawy w każdym grodzie położonym na terenie Korony i Litwy wprowadzono obowiązek prowadzenia ksiąg rejestrowych, w których ujawniane miały być wszelkie obciążenia i zobowiązania osób zamieszkałych na terenie jego właściwości (województwa, powiatu) w celu zapewnienia jawności kredytowej i kontroli długów szlacheckich. W przypadku, gdyby debitor (dłużnik) zaciągał zobowiązanie finansowe poza granicami powiatu, w którym zamieszkiwał, ustawa nakładała na wierzyciela (kredytora) obowiązek przeniesienia dokumentu stanowiącego podstawę udzielonego kredytu w postaci zapisu urzędowego lub prywatnego w postaci karty ręcznej lub weksla ${ }^{60}$ do ksiąg właściwych ze względu na zamieszkanie dłużnika, pod rygorem utraty pożyczonej sumy, jeżeli tego nie uczynił (zaoblatował) w terminie roku i 6 niedziel. Zauważyć należy, że wprowadzone rozwiązania prawne, nakazujące stronom kontraktu ujawnianie wszelkich dokumentów stanowiących dowód zaciągniętych zobowiązań finansowych w odrębnych protokołach właściwych ze względu na miejsce zamieszkania dłużnika, w zakreślonym terminie oblaty, obwarowane było sankcją utraty należnej sumy, a nie tylko ochrony prawnej w postaci rzeczowego zabezpieczenia (hipoteki) pożyczonej kwoty pieniężnej. Ponadto ustawa dopuściła możliwość dokonania oblaty dokumentu prywatnego (karta ręczna, weksel), przez nikogo niepoświadczonego, czy też potwierdzonego przez samego dłużnika, który samodzielnie mógł stanowić podstawę obciążenia hipotecznego ${ }^{61}$.

Przedstawione w artykule rozważania dotyczące kształtowania się instytucji ksiąg gruntowych, na tle zmieniających się zasad ustanawiania, przenoszenia i obciążania nieruchomości, służyć miały uwypukleniu typowych cech i funkcji, jakie pełniły one na przestrzeniu wieków w systemie prawnym państwa polskiego od czasów najdawniejszych do okresu pierwszego jego rozbioru. Podkreślenia wymaga, że stosowane wówczas w Polsce rozwiązania określające sposoby ustanawiania i przenoszenia prawa własności nie odbiegały zasadniczo od norm obowiązujących w tamtym czasie w większości krajów europejskich, a wręcz przeciwnie często je wyprzedzały, czego przykładem może być przyjęta w 1588 r. podczas sejmu koronacyjnego Zygmunta III ustawa o „ważności zapisów”. Zapisane zostały w niej rozwiązania systemowe, które wyprzedzały o dwa stulecia ustawodawstwa większości krajów eu-

\footnotetext{
${ }^{59}$ Vol. leg. VIII, s. 111 (poz. 178).

${ }^{60}$ Por. Vol. leg. VIII, s. 119 (poz. 192).

${ }^{61}$ W. Dutkiewicz, Prawo hipoteczne..., s. 15-16.
} 
ropejskich w tym zakresie, przyjmując jako powszechnie obowiązującą zasadę jawności formalnej i materialnej hipoteki, legalności hipoteki, swobody obciążania hipotecznego, szczegółowości czy pierwszeństwa wpisu, a także zasadę dobrej wiary ksiąg rejestrowych. Przyjęte wówczas zasady ustanawiania hipoteki, jako rzeczowego sposobu zabezpieczenia wierzytelności, stanowiły ustawową przesłankę zobowiązująca organy państwa do tworzenia i prowadzenia publicznych ksiąg gruntowych (sądowych, grodzkich, ziemskich), w których rejestrowane były prawa rzeczowe obciążające nieruchomość stanowiącą przedmiot zabezpieczenia. Przyjęte w 1588 r. rozwiązania określające sposoby i tryb ustanawiania hipoteki, ustalające jednocześnie zasady prowadzenia ksiąg gruntowych przetrwały w polskim porządku prawnym bez jakichkolwiek zmian przeszło dwa stulecia, aż do uchwalenia Konstytucji z 1768 i 1775 r., zmieniających te zasady, których celem było, w zamierzeniu ich pomysłodawców, udoskonalenie istniejącego porządku prawnego w tym zakresie. Praktyka stosowania tych przepisów zweryfikowała jednak założenia stanowiące przesłanki nowelizacji ustawy „o ważności zapisów”, a tym samym osłabiła instytucję ksiąg gruntowych i hipoteki. Podejmowane w okresie późniejszym działania reformatorskie nie zostały jednak ukończone z powodu kresu istnienia niezależnego państwa polskiego.

\section{PROPERTY RECORDS IN OLDER POLAND}

\section{Summary}

The paper outlines the history of land cadastres and land and mortgage registers in Poland from the earliest times until the first Partition. Against the background of the changing principles of establishing ownership, transferring or encumbering it with rights in rem or creating obligations over it, the paper describes how land and mortgage registers developed. They were modern public registers, which introduced the Polish mortgage into the legal system. Its design was far ahead of the legislation of most European countries at that time. The novelties included the principles of free access to, and reliability of, a mortgage, its legality, freedom of encumbrance, detailed character, priority of entry and, finally, the principle of good faith of registers.

\section{LES REGISTRES IMMOBILIERS DANS L'ANCIENNE POLOGNE}

\section{Résumé}

Nous trouvons dans l'article une esquisse historique portant sur la création du cadastre et des livres fonciers en Pologne, suivant un ordre chronologique depuis les 
temps les plus anciens jusqu'au premier partage de Pologne. Eu égard aux règles de conférer le droit de propriété en changement, le transfert des droits et le fait de grever des droits réels et droits des obligations, l'article présente le processus de création des livres fonciers, comme un registre public moderne, introduisant dans l'ordre public l'institution de l'hypothèque polonaise, entre autres. A l'époque, cette dernière avec les solutions qu'elle propose, dévance les législations de la plupart des pays européens, adoptant comme norme une règle étant généralement en vigueur, à savoir celle de la publicité formelle et matérielle de l'hypothèque, sa légalité, la liberté d'hypothéquer, de renseigner les détails ou la priorité d'inscription ainsi que la règle de bonne foi des répertoirs d'enregistrement. 